\title{
Gender Constructions in Early Childhood Education
}

\author{
Lia Aprilianti ${ }^{1, *}$, Vina Adriany ${ }^{2}$,Ernawulan Syaodih ${ }^{3}$ \\ ${ }^{1,2,3}$ Department of Early Childhood Education of Postgraduate Studies. Universitas Pendidikan Indonesia. \\ ${ }^{*}$ Corresponding author. Email: lia@upi.edu
}

\begin{abstract}
This paper discusses the construction of gender in early childhood education. Many studies that discuss this topic have been conducted both nationally and internationally. Internationally, research on gender in early childhood adopts critical theories that masculinity and femininity as something fluid and negotiated. The perception of men as the centre of the society's structure has been in equality a strong patriarchal culture in Indonesia. In the field of early childhood education, research that adopts critical theories on gender are still very scarce. This paper aims to expand previous studies by adopting Bourdieu's lens to analyse the extent to which social structure and class are intersected with gender construction. Using a literature study, finding of this paper is hoped to contribute to the debate and theories on gender in the early years.
\end{abstract}

Keywords: Gender, early childhood education, Bourdieu theory.

\section{INTRODUCTION}

This paper aims to expand the study of gender construction in early childhood education settings. Research on gender topics has been carried out both nationally and internationally [1]. Internationally, research on gender topics is mostly raised by analysis using a critical theoretical framework [2]. It was found that gender is a concept that is flexible to be discussed, as well as something that is still negotiable [3]. Meanwhile in Indonesia, the discussion of gender using critical theory is still rarely done [4].

Critical theory needs to be used as a lens in analyzing gender in the realm of early childhood education, which is still very gendered, both in terms of the learning approach used to the media provided by preschool institutions. Another important point that shows early childhood education in Indonesia is still very gendered is that the patriarchal culture that has long been rooted in Indonesia has contributed significantly to how gender is constructed [5]. As when playing, girls are directed to choose dolls over toy cars, he argues. This is followed by how teachers treat their students in learning activities, so that education is gender biased [6], differences arise, and restrictions in accessing opportunities, knowledge, experiences, and are limited in developing their agency.

Through a literature study approach [7] This paper will attempt to broaden the knowledge of how gender is constructed in early childhood education by focusing on the use of Bourdieu's theory. It is hoped that this article can contribute to open insights into the debate and theory on gender in early childhood.

\section{THEORETICAL FRAMEWORK}

This paper uses Bourdieu's theory in describing the practice of teaching and learning in early childhood education institutions which are still very gendered. Habitus, field, and capital are the three theoretical constructs used to develop a sensitive sociocultural model in practice between agents/actors and the reproduction of inequalities in the social world, one of which is gender inequality in accessing education [8].

Social construction is obtained through the approach of naturally acquired intellectual experience. Usually this is obtained because of the closeness to the concept of knowledge and ideas that are connected between time and conditions, and that social life is diverse and through essential processes [9]. Habitus in Bourdieu's work refers to a system of dispositions which are manifested through practices adapted to cultural and social structural principles. A sustainable cultural cycle is generated through internalization and outreach. Cultural production is not a closed result but a process that is produced repeatedly so that it becomes a structured culture [10].

The concept of habitus mediates between structural principles as a property of culture and structural principles as a property of practice is a structured embodiment of these principles [11]. It can be translated operationally from this theory that educational 
institutions, in this case early childhood education (ECE) institutions, have become cultural agents that legalize social class differences which produces differences. One of them is the interpretation of gender [12]. How the treatment of teachers or educators on children is differentiated by gender, the broader is the opportunity to explore opportunities to gain knowledge and learning experiences. An example is that boys will be given the opportunity to explore activities that emphasize the role and nature of masculinity in them [13]. Meanwhile, girls are more directed to choose and carry out feminine activities. So that if there are girls who play in areas that are claimed to be boys' activities, they will be considered different or out of the ordinary [14]. This is evidence of the differences mentioned by Bourdieu because they are produced by the culture and social structure of society in which educators have experienced this before. So that it is reproduced when he/she or they teach children in ECE institutions. It is then becoming a repetitive habitus. Namely, the behaviors of producing and reproducing the values, characters or styles that exist in the environment [15].

\subsection{ECE Institution as Sites of Gender Construction Production}

From the perspective of habitus, education is actually a re-formation of various kinds of differences. because schools have become agents in producing or reproducing a social class [16]. Bourdieu's theory is one of the post structuralist approaches that can be used as a reference and point of view in solving these problems. Research states that the study of gender is a sensitive area and has its own complexities [17], through various opinions and opinions on how gender is constructed in early childhood education institutions that are consistent and focus on child development, and of course the important role of educators in supporting this, but also implicitly or explicitly lead to gender stereotypes that take place continuously and become the environment and established social values.

This is a form of opposition from liberal thought which states education as a form of equality [15]. The form of social class differences is summarized in various ways, more specifically in my writing, in the class and social structure towards gender [18] that it becomes an identity through stereotypes [19].

The social structure and Habitus theory proposed by Bourdieu is used to find out how the social structure and Habitus that exists in early childhood education institution has implications for determining behaviors and educational services provided to boys and girls on a gender basis [20]. This is done because early childhood, as part of the social structure of society, is often considered not important to be involved in the concept of gender and its complexities. But on the other hand, this perception greatly influences what is appropriate and inappropriate for boys and girls [21], a small example that is closest to the world of early childhood education is in play. Boys are more involved in games that involve construction, physicality, and planned sports. Meanwhile, girls are more involved in literacy activities, fine motor skills, and others. This is reinforced by research conducted by Mascaro et al. [22] which found that teachers and parents promote various types of games to boys and girls. Boys are encouraged to be more involved in physical, constructive, and mechanical play. They are more often given prizes in the form of legos, vehicles, sports equipment and equipment. Girls, on the other hand, are more likely to be given dolls, kitchen utensils and art kits.

Discourse socialization is internalized into a gender nuance so that a gender identity continues to develop. The results of this gender socialization can be seen in the behaviors of children aged one to two years, when they begin to show a clear preference for toys that seem to match the gender markers they show. Based on research conducted by O'Connor et al. [13] that when boys and girls are socialized into gender-specific games, this must be addressed by society and more specifically, by educators. Why? Because play is actually not genderexclusive; Boys and girls have the right to experience, and the need to experience, all kinds of play [22]. Imaginative play develops communication skills, interpersonal skills, negotiation skills, encourages collaboration and enhances creativity. Physical play builds the cerebellum, supports the development of strength, endurance, resilience and self-confidence; all skills that are transferable into the academic setting from middle childhood onwards. Construction games improve visual-spatial coordination skills and, both of which are important in mathematical reasoning. Each type of play has holistic developmental benefits for children, regardless of gender. Balance in play is necessary and therefore games should not be divided along gender lines [22].

\subsection{Teachers Perception of Gender in Early Childhood}

Gender according to Puspitawati [23], is a concept used to identify differences between men and women, seen from the social and cultural aspects. So, it can be said that gender is a non-biological perspective. So that the word gender is different from the word sex. Sex is the concept of differentiation between men and women based on the reality or biological structure of humans. That between women and men are naturally different from their biological aspects is clear and cannot be denied. Women have a different form of sex with men. This sex difference, not infrequently, then affects the construction of gender in social reality. Gender differences between women and men occur through a long process and even begin at an early age. Due to the 
physical differences between women and men, it demands certain roles from these two creatures which are then socialized, internalized from generation to generation and even by using regulations from various perspectives such as religion, belief, culture, and so on. So that it is as if the gender construction becomes a natural, immutable truth, such as the status and existence of differences in sex or sex. As previously mentioned, the concept of gender formation is carried out from an early age, so the teacher as the closest environment to students also shapes how gender is constructed. So that it results in the emergence of gender injustice in school institutions [14]. One of the common things about gender inequality occurs because we live in a dominant society with ideas about how to be right for men and women.

Differences in gender roles become evident in children at an early age, Maccoby Whiting and Edwards [24] states that boys and girls who are in the age range of 3 years show different communication styles, participate in different activities, play more often with same-sex friends, and tend to avoid making friends with the opposite sex. This is believed to be a form influenced by the encouragement of educators for children to play based on gender differences [25], boy with boy, and vice versa. This continues to be applied as something normal, although the concept of gender is starting to be widely understood.

This view does not take into account the impact and limitations that gender can have on a child's sense of identity. Society has linked the division of people into men and women so closely with our understanding of identity that it is generally understood as fact rather than something we have learned to see as natural [24]. The separation of men and women through restrictive gender roles, which is determined by previous work demands, such as men as protectors of women, and women as complementary in men's lives. However, this is not appropriate to the current context. We must recognize gender formation in the relevant context.

\section{CONCLUSION}

Bourdieu's theory is one of the post structuralist approaches used as a reference and viewpoint in this paper. A similar writing has been done by Gorelay, et al. [11] which examines the concept of gender, and Bourdieu's theory in the realm of educational institutions. Specifically, in this article, early childhood education institutions have become a culture in producing values, norms, lifestyles, and views on how gender in early childhood is constructed. This then has implications for the occurrence of segregation which is very contrasting between the identity and expectations of boys and girls, because it is based on the characteristics generally applied to men and women.
Thus, resulting in marginalized parties with restrictions in accessing experience and sources of knowledge provided by early childhood education institutions, so that the knowledge process that should be obtained by being carried out and efforts to accommodate them in accessing knowledge becomes very narrow and is detrimental to boys and girls as the subject of the perpetrators. This can be referred to as neglect of children's rights which adults do not realize, in this case the teacher as a figure implementing pedagogy in the school environment.

In fact, all learning and experience sources can be accessed by all children without gender differences, because they can provide various benefits and benefits for boys and girls. Through this, it is hoped that the creation of gender justice and justice in obtaining the right to education. This can be referred to as neglect of children's rights which adults do not realize, in this case the teacher as a figure implementing pedagogy in the school environment.

Learning environment for children in early childhood education institutions needs to be built by applying the values and principles of justice. The principle of justice applied in aims to fully support the potential of students without differences in biological forms, so it is hoped that the creation of educational institutions that promote education with justice, sensitivity and gender responsiveness. These objectives are as follows: a) To form quality Indonesian children, namely children who grow and develop according to their level of development so that they have optimal readiness to enter basic education and navigate life in adulthood without being shackled by standard gender roles and harms either gender. b) To help boys and girls achieve primary school (academic) learning readiness. c). Optimally developing all the potential of boys and girls. d). Inculcating values and norms of life that prioritize the values of justice and gender equality. e) Forming and habituating expected behaviors by prioritizing competency values that are not gender biased. f) Development of children's basic knowledge and skills according to their potential and interests. g) Development of motivation and positive learning attitudes for boys and girls. The goals to be achieved must of course be pursued through a comprehensive upstream to downstream effort, and solid cooperation between practitioners and educational administrators. Thus, early childhood education institutions become institutions that develop and produce a culture with the values of justice for all students, both boys and girls.

\section{REFERENCES}

[1] Warin J, Adriany V. Gender flexible pedagogy in early childhood education. Journal of Gender Study [Internet]. 2017;26(4):375-86. Available from: http://dx.doi.org/10.1080/09589236.2015.1105738. 
[2] Edgerton JD, Peter T, Roberts LW. Gendered habitus and gender differences in academic achievement. Alberta Journal of Educational Resarch. 2014;60(1):182-12. Available from: https://doi.org/10.1007/3-540-11494-7_22.

[3] Eccles JS, Jacobs JE, Harold RD. Gender role stereotypes, expectancy effects, and parents' socialization of gender differences. Journal of Social Issues. 1990; 46 (2):183-201.

[4] Adriany V. Being a princess: young children's negotiation of femininities in a Kindergarten classroom in Indonesia. Gender and Education [Internet]. 2019;31(6):724-41. Available from: https://doi.org/10.1080/09540253.2018.1496229.

[5] Sakina AI. Menyoroti budaya patriarki di Indonesia. Share: Social Work Journal. 2017 Jul 30;7(1):71-80.

[6] Adriany V, Warin J. Preschool teachers' approaches to care and gender differences within a childcentered pedagogy: Findings from an Indonesian kindergarten. International Journal of Early Years Education. 2014; 22 (3):315-28.

[7] Xiao Y, Watson M. Guidance on conducting a systematic literature review. Journal of Planning Education and Research. 2019 Mar;39(1):93-112.

[8] Houston S. Reflecting on habitus, field and capital: Towards a culturally sensitive social work. Journal of Social Work. 2002 Aug;2(2):149-67.

[9] Harrits GS. Political power as symbolic capital and symbolic violence. Journal of Political Power. 2011 August 1;492):237-58.

[10] Bourdieu P, Passeron JC, Nice R. Education, society and culture. Trans. Richard Nice. London: SAGE Publisher. 1977.

[11] Gorely T, Holroyd R, Kirk D. Muscularity, the habitus and the social construction of gender: Towards a gender-relevant physical education. British Journal of Sociology and Education. 2003;24(4):429-48.

[12] Mirembe R, Davies L. Is schooling a risk? Gender, power relations, and school culture in Uganda. Gender and Education. 2001;13(4):401-16.

[13] O'Connor D, McCormack M, Robinson C, O'Rourke V. Boys and girls come out to play: Gender differences in children's play patterns. In 9th International Conference on Education and New Learning Technologies. 2017; 13(4):4713-19.

[14] Adriany V. 'I don't want to play with the Barbie boy': Understanding gender-based bullying in a kindergarten in Indonesia. International Journal of Bullying Prevention. 2019;1(4):246-54.

[15] Martínez-Bello VE, Cabrera García-Ochoa Y, Díaz- Barahona J, Bernabé-Villodre $\mathrm{M}$ del $\mathrm{M}$.
Bodies in the early childhood education classroom: a Bourdieusian analysis of curricular materials. Sport Education and Social [Internet]. 2019;26(1):29-44. Available from: https://doi.org/10.1080/13573322.2019.1690442.

[16] Nicolaescu C. Bourdieu: habitus, symbolic violence, the gift: "you give me/I give you" Principle. Euromentor Journal. 2010;1(3):1-10.

[17] Banks JA. Equity pedagogy: An essential component of multicultural education. Theory into Practice. 1995;34(3):152-8.

[18] Chapman R. A case study of gendered play in preschools: how early childhood educators' perceptions of gender influence children's play. Early Child Development and Care. 2016 August 2; 186(8):1271-84.

[19] Ramdaeni S, Adriany V, Yulindrasari H. Gender, power and play in early childhood education. In Proceeding of the $1^{\text {st }}$ International Conference on Educational Sciences (ICES 2017). 2018.109-14p. DOI: https://doi.org/10.5220/0007046006580663.

[20] Bourdieu P. Distinction: A social critique of the judgement of taste. New York: Harvard university press; 1984.

[21] Magnuson KA, Kelchen R, Duncan GJ, Schindler HS, Shager H, Yoshikawa H. Do the effects of early childhood education programs differ by gender? A meta-analysis. Early childhood research quarterly. 2016 Jul 1;36:521-36.

[22] Mascaro JS, et al. Child gender influences paternal behavior, language, and brain function. Behavioral Neuroscience. 2017;131(3):262-73. DOI https://doi.org/10.1037/bne0000199.

[23] Puspitawati H. Konsep, teori dan analisis gender. Bogor: Departemen Ilmu Keluarga dan Konsumen Fakultas Ekologi Manusia Institut Pertanian; 2013.

[24] Edwards CP, Whiting BB. Differential socialization of girls and boys in light of cross-cultural research. New Directions for Child and Adolescent Development. 1980;1980(8):45-57.

[25] Brody DL. The construction of masculine identity among men who work with young children, an international perspective. European Early Childhood Education Research Journal 2015;23(3):351-361. 